\title{
Spirometry Alteration Due to Exposure to Atmospheric Pollutants in Rural Homes in Bogotá, Colombia
}

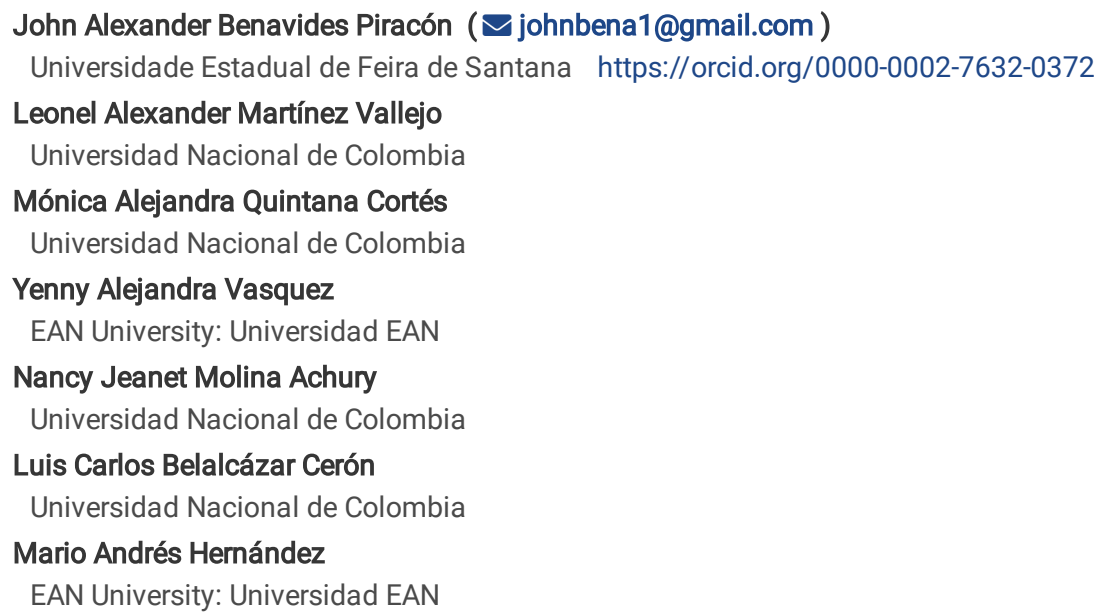

\section{Research Article}

Keywords: Respiratory function, PM2.5, black carbon, carbon monoxide, spirometry, particulate Matter

Posted Date: February 9th, 2021

DOI: https://doi.org/10.21203/rs.3.rs-173077/v1

License: (c) (i) This work is licensed under a Creative Commons Attribution 4.0 International License. Read Full License 


\section{Abstract}

This study was aimed to determine the association between the concentrations of particulate matter less than 2.5 microns ( $P M_{2.5}$ ), carbon monoxide (CO) and black carbon (BC) within the home and alterations in respiratory function in a population living in rural dwellings in the districts of Usme and Sumapaz in Bogotá, Colombia. Cross-sectional study that recruited people from the rural area of Bogotá. In total, 68 participants were recruited by nonrandom sampling. Indoor air monitoring of $\mathrm{PM}_{2.5}, \mathrm{BC}$ and $\mathrm{CO}$ were carried out. Additionally, a pulmonary function evaluation was performed using spirometry. Pulmonary function variables were included in a multiple linear regression by successive steps, adjusted in terms of the main variables described as modifiers of the values in spirometry, these are: age, height, sex and history of tobacco use. Assumptions of multicollinearity and randomization of variances in the residuals were evaluated. Negative associations were found between spirometry parameters and the concentration of indoor air pollutants. For FEV1 / FVC and theoretical FEV1 there was a statistically significant association with the concentration of carbon monoxide (p $=0.003$ and 0.019). Environmental concentrations were higher in homes where biomass is used for cooking these differences were only statistically significant for $\mathrm{BC}$ and $\mathrm{CO}(\mathrm{p}=0.008$ and 0.03 respectively). Carbon monoxide concentrations in rural homes caused alterations in respiratory function.

\section{Introduction}

In the world, approximately 2.8 billion people use solid fuels for cooking (wood, animal manure, agricultural waste, vegetal charcoal and charcoal), mainly among rural and low-income populations (Bonjour, et al., 2013). The combustion of this type of solid energy sources leads to high levels of indoor air pollution (IAP), which depends on the system used to cook the food.

The inefficiency of cookstoves results in the emission of pollutants such as particulate matter and elemental carbon, which vary according to the type of stove and fossil fuel used (MacCarty et al., 2010; Price-Allison et al., 2019). Additionally, potentially harmful chemical compounds are released, including carbon monoxide (CO), nitrogen dioxide (NO2), sulfur dioxide (SO2) and polycyclic aromatic hydrocarbons (Naeher et al., 2007; Steinvil et al., 2008; PriceAllison et al., 2019). Health effects of indoor air pollution include increased blood pressure, dyspnea, childhood pneumonia, lung cancer, low birth weight, and cardiovascular disease (Pratiti et al., 2020).

In this way, IAP problems are recognized as important risk factors for human health. Indoor air pollution has been associated with 3.5 million deaths and it causes $4.5 \%$ of the lost years of life due to disability in the world during 2010 (Lim, et al., 2012). A systematic review with meta-analysis shows that there were positive associations between the use of solid fuels and Chronic Obstructive Pulmonary Disease (COPD) (OR = 2.80, $95 \% \mathrm{Cl} 1.85$ to 4.0$)$ and chronic bronchitis ( $\mathrm{OR}=2.32,95 \% \mathrm{Cl} 1.92$ to 2.80$)$, also show that exposure to wood smoke, while doing housework, presents a greater risk of developing COPD and chronic bronchitis than other fuels. Therefore, efforts are recommended to reduce the use of this type of solid fuel (Kurmi et al., 2010). In this sense, IAP is a global public health threat that requires efforts from research and policy formulation (Alvis-Guzmán \& De la Hoz-Restrepo, 2008).

Regarding Colombia, the national survey of quality of life carried out by the National Administrative Department of Statistics (DANE) in 2018, shows that $21.7 \%$ of the population uses firewood as fuel for cooking (DANE, 2018). In a study conducted on a total of 2.1 million inhabitants living in extreme poverty in Colombia, the use of solid fuels for cooking food was 20 times higher in the rural population and almost three times higher in indigenous ethnic groups. Furthermore, the authors report an increase in the prevalence of cardiorespiratory limitations, as well as vision limitation (Soto-Moreno \& Ballester-Díez, 2013). According to the National Planning Department (DNP), morbidity related to indoor air pollution was estimated at more than one million cases per year and more than two thousand deaths from this cause nationwide (National Planning Department, 2018).

Carbon monoxide (CO), black carbon (BC), and particulate matter $\left(\mathrm{PM}_{2.5}\right)$ have been used as indicators of the components of indoor air that affect people's health. Particulate matter and carbon monoxide have been used in various studies to determine exposure to indoor and outdoor air pollution and have been associated with alterations in respiratory function measured by spirometry or respiratory symptoms (Steinvil et al., 2008; Steinvil et al., 2009; Pope et al., 2015). In a cohort study that evaluated mean environmental concentrations of various pollutants, including black carbon, it was significantly associated with increases in the proportion of emphysema during the 10-year follow-up (Wang et al., 2019). Likewise, the effects of black carbon on health problems can be seven or eight times greater than those related to $\mathrm{PM}_{2.5}$. In any case, the concentrations of these two pollutants directly impact the life expectancy of the exposed population (Janssen et al., 2011).

AIP can affect all population groups, as well as those vulnerable due to their health or age, such as people suffering from heart, respiratory, cognitive, physical or other conditions which might make them stay most of the time at home, thus increasing their exhibition (Bruce, Perez-Padilla, \& Albalak, 2000). However, in Colombia, current scientific studies are mostly focused on outdoor air quality, without recognizing the possible sources of indoor pollutant emissions, or monitoring the concentrations inside the house to which those who remain for longer time are exposed, such as women, children, and older adults. For these reasons, the objective of this study is to determine the association between concentrations of $\mathrm{PM}_{2.5}, \mathrm{CO}$ and intradomiciliary $\mathrm{BC}$ and alterations in respiratory function in a population of inhabitants of rural dwellings in the districts of Usme and Sumapaz in Bogotá.

\section{Materials And Methods}

\subsection{Study Area}

The research was carried out in the rural territories of Usme and Sumapaz (Bogotá, Colombia) located between 2,600 and 3,100 meters above sea level, it is located $31 \mathrm{~km}$ from the urban area of Bogotá, with a temperature that ranges between 4 and $19{ }^{\circ} \mathrm{C}$ (District Planning Secretariat, 2020). All the 
monitored houses were built in brick and cement, and because it is a rural area, the houses were scattered, that is, they were not close to each other, forming a neighborhood. It is important to highlight that, due to the temperature conditions, the use of stoves represents a heating alternative for rural homes, which in the face of spaces with limited ventilation contributes to the accumulation of pollutants.

\subsection{Population}

The research was developed from a cross-sectional study that recruited inhabitants of rural houses. The inclusion criteria included people who lived in rural homes in the towns of Usme and Sumapaz, it was established that they had lived for at least one year in the rural region. For the evaluation of pulmonary function, people who had respiratory symptoms such as coughing, expectoration or dyspnea, health conditions that prevented the performance of spirometry, as well as people who were unable to perform the maneuver for the examination were excluded.

Due to the geographic dispersion of the region and the limitation of resources of the study initially, it was established to calculate a sample size of 50 individuals with a confidence of $95 \%$ and a prevalence of COPD in rural areas of $15 \%$ and an error of $10 \%$; however, the study resources allowed obtaining a total of 68 participants with an estimate of the standard error of $8 \%$.

Regarding the measurement of air quality, in some homes the evaluation equipment was manipulated or disconnected from the electrical sources by the participants, which caused loss in the evaluations of the environmental variables for 19 people. Environmental and lung function assessments were carried out over a 4-month period between November 2018 and February 2019.

\subsection{Air pollutant monitoring}

In the indoor air quality monitoring, levels of particulate matter of less than 2.5 microns, as well as black carbon and carbon monoxide were measured. In this study, the measurement site was a room or living room that was always adjoining the kitchen. The measurement was carried out for at least 48 continuous hours for $\mathrm{PM}_{2.5}$ and $\mathrm{CO}$, and 12 hours for black carbon in each of the houses.

Particulate matter: the Dusttrak II 8530 aerosol pollutant monitor was used to monitor particulate matter. This instrument uses optical dispersion to deliver real-time concentrations of $\mathrm{PM}_{2.5}$. The detection range is 0.001 to $400 \mathrm{mg} / \mathrm{m} 3$ with a resolution greater than $0.001 \mathrm{mg} / \mathrm{m}^{3}$ or $1 \%$ of the reading. The instrument was operated with a factory default setting of $3.0 \mathrm{~L} / \mathrm{min}$ for the impactor to achieve the correct cut-off points. It was used and validated in reference studies (Canha et al., 2017; McNamara et al., 2017; Wang et al., 2016). The equipment was zeroed before each monitoring, the impact plate was cleaned and greased, and the $37 \mathrm{~mm}$ mesh filter was cleaned before measurements.

Black carbon: the concentration of $\mathrm{BC}$ in the $\mathrm{PM}_{2.5}$ fraction was measured with the MicroAethalometer model $\mathrm{AE} 51$, an equipment which measures the transmission of light at $880 \mathrm{~nm}$ through the active area of the filter (detection channel) in which the BC is collected. Also, it normalizes the detection channel results to changes in a reference channel, which monitors with a sample fraction of the same filter. The MicroAethalometer has been used in similar studies (Kar et al., 2012; De la Sota et al., 2018; Wierzbicka et al., 2018).

Carbon monoxide: Carbon monoxide was determined with the Q-trak Model 7575 Indoor Air Quality Monitor; It is a multi-function electrochemical sensor, which can measure $\mathrm{CO}$, carbon dioxide ( $\mathrm{CO} 2)$, temperature and relative humidity $(\mathrm{RH})$. It uses an electrochemical sensor to measure the $\mathrm{CO}$ concentration range from 0 to $500 \mathrm{ppm}$ with an accuracy of $\pm 3 \%$ of reading or $3 \mathrm{ppm}$ (whichever is greater), a non-dispersive infrared (NDIR) sensor to determine the CO2 concentration between 0 and $5000 \mathrm{pm}$ with an accuracy of $\pm 3 \%$ of reading or $\pm 50 \mathrm{ppm}$ (whichever is greater), a thermistor to measure the temperature between 0 and $60{ }^{\circ} \mathrm{C}$ with an accuracy of $\pm 0.5^{\circ} \mathrm{C}$ and a thin-film capacitive element to measure relative humidity between 5 and $95 \%$ with an accuracy of $\pm 3 \%(T S I, 2018)$.

The data reported by the equipment, being in real time, requires post-processing, applying correction factors for DustTrak and Microaethalometer widely studied (McNamara et al, 2011; Perera \& Litton, 2015).

Measurements obtained with the DusTrak require calibrations to improve the precision of concentrations when evaluating specific sources, for example, biomass combustion, cooking, diesel exhaust gases, among others (Rivas et al., 2017; Li et al., 2019). Furthermore, the results produced by optical samplers, such as the DustTrak, have been shown to differ when compared to gravimetric sampling methods. For this reason, the PM 2.5 concentration data obtained in this study were applied the correction factor established by McNamara (2011) which was developed specifically for the use of firewood as fuel in indoor environments.

Similarly, black carbon measurements made with the MicroAethalometer are affected by multiple factors, including noise due to small random fluctuations in digitized signals and changes in the signal as a result of incremental loading of particles on the filter. For measurements, attenuation (ATN) is expected to increase as load on the filter spot increases; however, deviations from this monotonic relationship often result from electronic noise. Since the calculations are performed for successive ATN differences, negative values may appear and should be corrected. Therefore, the correction is made to the data obtained through processing used in reference studies (Cai et al. 2013; Good et al., 2017).

The place within the home was selected to locate the equipment, according to the permanence of the person in the home. It was carried out in this way taking into account what was done by Barría \& Calvo, 2016, defining the height of the measurement according to the height of the person, on average $1.53 \mathrm{~m}$ in height, the location height ranged between $0.9 \mathrm{~m}$ and $1.70 \mathrm{~m}$. The monitoring equipment was located in the room at $1.5 \mathrm{~m}$ distance from each

Page 3/15 
other, ensuring the least interference between devices and activities of daily life. The instruments had the annual calibration certified by the laboratory of origin in the USA Table 1 summarizes the information on the monitoring characteristics and the correction factors used for the PM $\mathrm{M}_{2.5}$ and $\mathrm{BC}$ readings.

Additionally, to obtain information that would allow an effective results analysis to be carried out, a question format was used, which is established based on what was done by Rumchev (2017) and considers both the characteristics of the dwelling and sociodemographic data additional to the one which had been already collected for the project (Rumchev, K. et al. (2017). Each home receives a format to keep track of the stove they use in order to contrast with the data recorded by the monitoring equipment. as well as to record emission activities, such as external events or use of the stove to produce products for commercial purposes.

\subsection{Lung function assessment}

After 48 hours of environmental monitoring, an evaluation of lung function was carried out. To do it, in each house, a table was located in a closed room where the spirometer, disposable mouthpieces, antibacterial filters were placed. Likewise, a computer to register the evaluation information was set next to it. To guarantee reproducibility and avoid biases in the collection of information, the spirometries were performed by a physiotherapist trained by an expert from the National University of Colombia. The training included handling, installation and performance tests of the equipment, time management to carry out the test, and voice commands for the motivation of the participants and unification of the test approval criteria. 5 piloting spirometries were performed in the Human Body Movement Department of the National University.

In order to carry out the spirometry, the professional explained the test to each participant. Then, there was a mock test which was corrected and provided feedback. Spirometry was performed following the protocol established by Miller et al (2005), who are part of the guidelines of the American Thorax Association and the European Respiratory Society. The equipment used was a SpiroBank $\mathrm{G}$ brand spirometer and Winspro software; the data was recorded in digital medium. The test was considered adequate after performing and recording 3 maneuvers which had met the acceptability criteria (correct start, stable plateau, plotting the curves without artifacts, slow and asymptotic termination and adequate duration), and repeatability criteria. The result of the maneuver that presented the least variability was selected (Miller et al., 2005).

In the same room, the physiotherapist evaluated the height with a height rod on a flat surface. Using a previously calibrated scale, body weight was determined, and oxygen saturation and heart rate were measured with a pulse oximeter.

The variables evaluated were the forced vital capacity (FVC) expressed in liters, the forced expiratory volume in the first second (FEV1) expressed in liters, the maximum expiratory flow (PEF) expressed in liters/seconds and the FEV1/FVC ratio ("Tiffeneau-Pinelli Index"). Finally, an index was established that relates FEV1the = FEV1 / (FEV1 PRE) and PEF1the = PEF / (PEF pre), this index establishes the proportion between the ideal values for the participant's height, weight and age and its relationship with the result obtained. In the analysis, these variables were considered since the FEV1 indicators and the FEV1/FVC ratio are the most sensitive and reproducible measurements to determine that there is bronchial airflow obstruction (Contreras \& Martinez, 2006; Liñán Cortés, Cobos Barroso \& Reverté Bover, 2008; Enright, Lebowitz \& Cockroft, 1994).

For the interpretation of the results, the comparison of the found values and the theoretical values established by the software under the formula Theoretical - Crapo \& Bass / Kundson corresponding to the Caucasian ethnic group was taken into account. To interpret spirometry results, lung function was classified according to the lower limit of normal (LLN) as follows: (1) restrictive defect, indicated by an FVC $<80 \%$, FEV $\leq 80 \%$, and FEV1/FVC $\geq$ LLN; (2) obstructive defect, indicated by a decrease in the FEV1/FVC ratio (less than 70\%), a FEV1 <80\% and an FVC $\geq$ LLN; (3) combined defect, indicated by FVC <LLN, FEV1 <LLN and the normal FEV1/FVC ratio, increased or decreased, depending on the pattern that predominates the most (Pellegrino, et al., 2005; Romero de Ávila Cabezón, and others, 2013).

\subsection{Statistical Analysis}

Statistical analysis of the data was performed for each of the pollutants under study, so that it would be possible to show the averages of the evaluations during the observed periods. In the evaluation variables of lung function, a description was made by means and standard deviation. For continuous variables, tests were performed to determine the normality of the distribution (Lilliefors, 1967). To make comparisons between the concentrations of pollutants and fuels used in cooking, non-parametric tests (Mann-Whitney test) were performed, with a significance $p$ value of 0.05 . To establish an association between the lung function variables and the mean concentrations of the pollutants, a bivariate correlation matrix was made, which used the Sperman test for contrast, with significance values of 0.05 .

Pulmonary function variables were included in a multiple linear regression by successive steps, adjusted for the main variables described as modifiers of the spirometry values, these are age, height, sex and history of tobacco use, multicollinearity assumptions were evaluated, randomization of variances in the residuals and the absence of influential individuals by extreme values that modify the model (Cook's distance). The data were analyzed in the SPSS software.

For the development of the project, the informed consent document was registered by a person of legal age living in each dwelling and was endorsed by the ethics committee of the EAN University.

\section{Results}




\subsection{Population and emission sources}

The population sample is mainly female with $66.2 \%$. They presented a low prevalence of tobacco consumption with only $10.3 \%$, with an average age of 42 years. The 68 people selected lived in 33 independent houses and in $64 \%$ of the homes there was at least one person with a disability. Regarding the stoves found in homes that consume wood as fuel, $98 \%$ were fireplaces, and $2 \%$ were a traditional type of stove (Figure 2 ). In the case of those that use gas as fuel, $100 \%$ of the households used a stove with a cylinder valve. The main sources of $\mathrm{PM}_{2.5}, \mathrm{BC}$ and $\mathrm{CO}$ emissions in the studied households are the use of solid fuel as firewood for cooking food and external burning of waste. When they occur, there are peaks in concentrations as evidenced in Figure 3 , where the concentrations are shown during a period of the day.

The concentrations of $\mathrm{PM}_{2.5}$ exceeded the recommendation of the world health organization: $25 \mu \mathrm{g} / \mathrm{m}^{3}$ in $55.8 \%$ ( $\mathrm{n}=38$ ) of the people in the sample. The $24 \mathrm{~h}$ average $\mathrm{PM}_{2.5}$ levels ranged from $6.27 \mu \mathrm{g} / \mathrm{m}^{3}$ to the maximum average of $220.19 \mu \mathrm{g} / \mathrm{m}^{3}$. As expected, the lowest 24 -hour average concentrations were obtained in homes where they cook with gas and the highest where they use firewood. As expected, carbon monoxide levels were not recorded in homes where gas is used; the detection limit of the equipment is 0 to 500 ppm. For households where firewood was used, the 24 -hour average of carbon monoxide concentrations was between $0.34 \mathrm{ppm}$ and $1.31 \mathrm{ppm}$.

Black carbon concentrations were always correlated with those of $\mathrm{PM}_{2.5}$, the evolution of pollutant concentrations during the measurement period. As an example, Figure 3 shows a home where they used firewood and Figure 4 shows the concentrations where they used gas. The $12 \mathrm{~h}$ average concentrations of black carbon measured were between $0.64 \mu \mathrm{g} / \mathrm{m}^{3}$ and $51.2 \mu \mathrm{g} / \mathrm{m}^{3}$. The concentrations were compared between the types of fuel used for cooking food inside homes, finding higher concentrations of all pollutants in homes where cooking with biomass, these differences were only statistically significant for $\mathrm{BC}$ and $\mathrm{CO}(\mathrm{p}=0.008$ and 0.03 , respectively).

Table 2 presents the proportion of women and men, weight, age, height, use of biomass, history of smoking. In addition, it summarizes the average concentrations from all monitoring, the patterns of obstruction, restriction, and characteristics from spirometry.

\subsection{Pulmonary function}

The study evaluated the interaction between the indoor air quality pollutants in homes and the respiratory variables (Table 3). Pulmonary function analyses revealed that the population had some type of spirometry alteration in $10.3 \%$ of the sample $(n=7) .7 .4 \%$ of the people had a restriction pattern $(n=5)$ and $1.5 \%$ had an obstructive pattern $(n=1)$ and a mixed pattern $(n=1)($ Table 2$)$.

The average respiratory flow FVC was 3.01 liters (DS 0.86), an FEV1 of 2.49 liters (DS = 0.776), the ratio between FEV1 / FVC on average is $82.2 \%(D S=$ 8.8).

Negative correlations were found between spirometry parameters and the concentration of indoor air pollutants. For FEV1/FVC, negative associations were found with all the pollutants evaluated, but there was only a statistically significant association with the concentration of carbon monoxide $(p=$ 0.003). For the theoretical FEV1 there was also a negative association with monoxide $(p=0.019)$ (Table 4).

A negative association was found between carbon monoxide concentrations and FEV1/FVC, theoretical FEV1 and PEF values, in the adjusted and unadjusted measurements (Table 4). The successive steps model excluded low inflation values of the variance. For $\mathrm{CO}$, however, when evaluating the adjusted residual values with respect to the predictor values we found a random pattern in the graph, when measuring the cook distance, we found only one case with extreme mean in the model, but it was the dwelling that used the most firewood for cooking food. The model was not statistically significant for the vital capacity FVC, FET.

\section{Discussion}

After searching the main academic databases, no publications were found on research in Colombia evaluating the association between $\mathrm{PM}_{2.5}$, carbon monoxide and black carbon and pulmonary function alterations in the rural population. Two relevant findings are derived from the present study: First, homes with solid fuel stoves reach average concentrations of $\mathrm{PM}_{2.5}$ higher than the levels established by the World Health Organization (25 $\mu \mathrm{g} / \mathrm{m} 3$ during $24 \mathrm{~h}$ ) and was higher when compared to homes where gas was used. In various studies, increased exposure to biomass combustion has been associated with reduced lung function in cross-sectional studies of populations from Bangladesh (Akther et al., 2019), Brazil (da Silva et al., 2012), Malawi (Fullerton et al., 2011) and Nepal (Pandey et al., 1985). Second, in this sample, CO altered the respiratory function of the people and showed a significant negative association in the adjusted measure for various indicators of the spirometry.

Incomplete burning of wood causes not only exposure to BC, PM and CO, but to a wide range of gases. In animal models, rats exposed to wood smoke showed systemic oxidative stress and increased expression of the catalytic subunit glutamate-cysteine ligase (GCLC) protein in the lungs, generating acute and chronic inflammatory processes that can cause chronic bronchitis (Hu et al., 2013). In human populations, experimental studies identified an increase in nitrogen dioxide and an inflammatory response and an increase in oxidative stress in the respiratory tract, particularly in the lower airways (Barregard et al., 2008; Swiston et al. 2008). In a population exposed to outdoor air pollution, different combustion gases and their impact on respiratory function were evaluated, finding a negative correlation between various gases, including $\mathrm{CO}$, but they were sulfur dioxide concentrations and their alterations in FEV (1) and FVC, these effects were maintained for up to 6 days (Steinvil et al., 2009).

Page 5/15 
Table 5 compares the $\mathrm{CO}$ concentrations measured in this study and the ambient concentrations reported in the Bogotá Air Quality Monitoring Network. It is evident that the 8-hour average concentrations of $\mathrm{CO}$ in homes where they use firewood can reach concentrations higher than those of the station closest to the monitoring site (Tunal Station) and is also higher than the highest average registered in the monitoring network (Puente Aranda) (District Secretary for the Environment, 2019). This reveals the high concentrations within households in this rural area and the importance of researching possible negative effects on people's health and strategies to improve air quality.

Other investigations against the association between $\mathrm{CO}$ and respiratory involvement in a rural area of Ghana in pregnant women ( $\mathrm{n}=840)$ reported a positive association between $\mathrm{CO}$ exposure by $1 \mathrm{ppm}$ increase and a composite score of respiratory symptoms such as current cough (that was > 5 days), wheezing and/or dyspnea (OR: 1.2, $p=0.03)$ and CO was also positively associated with wheezing (OR: $1.3, p=0.05)$, as well as with phlegm (OR: 1.2 , $p$ $=0.08)$ and visits to the clinic for respiratory infection were reported within the 4 weeks prior to the study $(0 R: 1.2, p=0.09)($ Van Vliet et al, 2019).

Likewise, other studies have found prevalence regarding the use of biomass and the presence of symptoms such as headache and/or recent respiratory symptoms (cough, wheezing, shortness of breath or runny nose) with the use of wood stoves and/or coal with or without a closed combustion chamber and chimney, taking into account that groups of people who used stoves without any protection had marginally higher prevalence. Biomarkers for indoor air pollution exposure were also positively associated with red, itchy and wet eyes and eye pain when cooking (Li, Z. et al, 2016). Furthermore, Li, S et al., (2019) found that exposure to the relative concentration of $\mathrm{PM}_{2.5}$ indoors was associated with an increased risk of asthma-like symptoms and presence of asthma in adult residents, as well as FVC values, FEV1 and PEF, particularly in winter (Li, S. et al, 2016). Nonetheless, the association between respiratory symptoms and the use of biomass and concentrations of $\mathrm{PM}_{2.5}$ is consistent in the scientific literature.

When comparing the concentrations of $\mathrm{PM}_{2.5}$, black carbon and carbon monoxide, a negative association was found between $\mathrm{PM}_{2.5}$ and spirometry alterations but it was not statistically significant. Therefore, exposure in homes to concentrations of particulate matter impacts the respiratory system, decreasing lung capacity. This is in line with what was found by Akther et al., (2019), where the peak flow rate decreased in response to the increase in concentrations of fine $\left(\mathrm{PM}_{2.5}\right)$ and ultrafine $\left(\mathrm{PM}_{1.0}\right)$ particulate material. The flow rate went from approximately $500 \mathrm{l} / \mathrm{min}$ to $370 \mathrm{l} / \mathrm{min}$ for people exposed to $\mathrm{PM}_{2.5}$ concentrations around $90 \mu \mathrm{g} / \mathrm{m}^{3}$. According to this, exposure to $\mathrm{PM}_{2.5}$ in rural homes in Usme and Sumapaz could cause a decrease of more than $26 \%$ in people's lung capacity, since the average $\mathrm{PM}_{2.5}$ concentrations in homes where they used firewood is of $85.3 \mu \mathrm{g} / \mathrm{m}^{3} \mathrm{which}$ are $10 \%$ higher than those reported by Akther et al., (2019).

On the other hand, in the crude and adjusted measurements, the $\mathrm{CO}$ altered several spirometry indicators in asymptomatic patients. In studies evaluating exposure to monoxide, no statistically significant associations were found. However, in a population of non-smoking women exposed to wood smoke, CO concentrations in exhaled breath were negatively associated with lower FEV1 (Pope et al., 2015). Likewise, the combustion of firewood may be related to the release of toxic substances and pro-inflammatory mediators that directly impact the frequency of respiratory infections (Corsini et al., 2017; Corsini, Marinovich, \& Vecchi., 2019).

\section{Conclusions}

Although these findings allow us to collect evidence of the impact of gases from the use of solid fuels on health, we must recognize that this research has numerous limitations, firstly, associated with its cross-sectional design that limits the monitoring of the population, as well as the identification of cumulative impacts to exposure. The geographic context of the Colombian rurality makes populations live in conditions of great dispersion and of difficult access. For this reason, individuals were selected by means of convenience. Additionally, the losses of environmental evaluation further limited the number of evaluations, thus limiting the external validity of the results, which must be considered when extrapolating these data to other populations.

Likewise, this study found associations between IAP and spirometry alterations. It is very important for the health of the rural population of Colombia to carry out studies that allow examining the changes in the incidence of chronic lung diseases and if it is possible to carry out interventions such as health policy to reduce exposure to IAP due to the use of solid fuel, and it will require larger sample size and/or duration of follow-up.

\section{Declarations}

Ethics approval: The study was approved by the ethic committee of the EAN University and the study was performed in accordance with the ethical standards as laid down in the 1964 Declaration of Helsinki.

Consent to participate: Informed consent was obtained from all individual participants included in the study.

Consent for publication: Not applicable

Availability of data and material: The content is solely the responsibility of the authors and does not necessarily represent the official views of the Institutions

Conflicts of interest/Competing interests: The authors declare that they have no conflict of interest.

Funding: This study is carried out within the framework of an agreement between EAN University and the Department of Human Body Movement of the National University of Colombia. It was financed by EAN University and is carried out in response to the needs and problems identified in previous studies 
which had been focused on the rural area of Bogotá and which had been developed by the two institutions.

Authors' contributions: All authors contributed to the study conception and design. Material preparation, data collection and analysis were performed by John Alexander Benavides Piracón, Leonel Alexander Martínez Vallejo, Mónica Alejandra Quintana Cortés, Yenny Alejandra Vasquez, Nancy Jeanet Molina Achury, Luis Carlos Belalcázar Cerón and Mario Andrés Hernández. The first draft of the manuscript was written by John Alexander Benavides Piracón and all authors commented on previous versions of the manuscript. All authors read and approved the final manuscript.

\section{References}

1. Akther, T., Ahmed, M., Shohel, M. et al. (2019). Particulate matters and gaseous pollutants in indoor environment and Association of ultra-fine particulate matters (PM1) with lung function. Environ Sci Pollut Res 26, 5475-5484. https://doi.org/10.1007/s11356-018-4043-2

2. Alvis-Guzmán, N., \& De la Hoz-Restrepo, F. (2008). contaminación del aire domiciliario y enfermedades respiratorias (infección respiratoria aguda baja, epoc, cáncer de pulmón y asma): evidencias de asociación. Rev. Fac. Med, 56(1), 54-64.

3. Barregard, L., Sallsten, G., Andersson, L., Almstrand, A., Gustafson, P., Andersson, M., \& Olin, A. (2008). Experimental exposure to wood smoke: effects on airway inflammation and oxidative stress. Occupational And Environmental Medicine, 65(5), 319-324. doi: 10.1136/oem.2006.032458

4. Barría, R., \& Calvo, M. (2016). Contaminación intradomiciliaria por material particulado fino (MP2,5) en hogares de recién nacidos. Revista Chilena de Pediatria, 87(5), 343-50.

5. Bonjour, S., Adair-Rohani, H., Wolf, J., Bruce, N., Mehta, S., Prüss-Ustün, A., . . Smith, K. (Jul de 2013). Solid fuel use for household cooking: country and regional estimates for 1980-2010. Environ Health Perspect, 121(7), 784-90. doi:10.1289/ehp.1205987

6. Bruce, Nigel, Perez-Padilla, Rogelio \& Albalak, Rachel. (2000). Indoor air pollution in developing countries : a major environmental and public health challenge / Nigel Bruce, Rogelio Perez-Padilla, and Rachel Albalak. Bulletin of the World Health Organization : the International Journal of Public Health 2000 ; 78(9) : 1078 -1092 https://apps.who.int/iris/handle/10665/57643

7. Cai, J., Yan, B., Kinney, P. L., Perzanowski, M. S., Jung, K. H., Li, T., ... Chillrud, S. N. (2013). Optimization approaches to ameliorate humidity and vibration related issues using the MicroAeth black carbon monitor for personal exposure measurement. Aerosol Science and Technology, 47(11), 1196-1204. https://doi.org/10.1080/02786826.2013.829551

8. Canha, N., Lage, J., Candeias, S., Alves, C., \& Almeida, S. M. (2017). Indoor air quality during sleep under different ventilation patterns. Atmospheric Pollution Research, 8(6), 1132-1142. https://doi.org/10.1016/j.apr.2017.05.004

9. Contreras Carreto, N., \& Martinez Quevedo, J. (2006). Utilidad de la espirometría en el paciente con EPOC. Medigraphic, 13(4), 156-160.

10. Corsini, E., Ozgen, S., Papale, A., Galbiati, V., Lonati, G., Fermo, P., Marinovich, M. (2017). Insights on wood combustion generated proinflammatory ultrafine particles (UFP). Toxicology Letters, 266, 74-84. https://doi:10.1016/j.toxlet.2016.12.005

11. Corsini, E., Marinovich, M., \& Vecchi, R. (2019). Ultrafine Particles from Residential Biomass Combustion: A Review on Experimental Data and Toxicological Response. International journal of molecular sciences, 20(20), 4992. https://doi.org/10.3390/ijms20204992

12. DANE. (2018). Encuesta nacional de calidad de vida. DANE, Bogotá.

13. da Silva, L. F., Saldiva, S. R., Saldiva, P. H., Dolhnikoff, M., \& Bandeira Científica Project (2012). Impaired lung function in individuals chronically exposed to biomass combustion. Environmental research, 112, 111-117. https://doi.org/10.1016/j.envres.2011.10.012

14. de la Sota, C., Lumbreras, J., Pérez, N., Ealo, M., Kane, M., Youm, I., \& Viana, M. (2018). Indoor air pollution from biomass cookstoves in rural Senegal. Energy for Sustainable Development, 43, 224-234. https://doi.org/10.1016/j.esd.2018.02.002

15. Departamento Nacional de Planeación. (2018). valoración económica de la degradación ambiental en colombia 2015. DNP, Bogotá.

16. Good, N., Mölter, A., Peel, J. L., \& Volckens, J. (2017). An accurate filter loading correction is essential for assessing personal exposure to black carbon using an Aethalometer. Journal of exposure science \& environmental epidemiology, 27(4), 409-416. https://doi.org/10.1038/jes.2016.71

17. Enright, P., Lebowitz, M., \& Cockroft, D. (1994). Physiologic Measures: Pulmonary Function Tests. American Journal Of Respiratory And Critical Care Medicine, 149(2_pt_2), S9-S18. doi: 10.1164/ajrccm/149.2_pt_2.s9

18. Fullerton, D. G., Suseno, A., Semple, S., Kalambo, F., Malamba, R., White, S., Jack, S., Calverley, P. M., \& Gordon, S. B. (2011). Wood smoke exposure, poverty and impaired lung function in Malawian adults. The international journal of tuberculosis and lung disease: the official journal of the International Union against Tuberculosis and Lung Disease, 15(3), 391-398.

19. Hu, G., Zhou, Y., Hong, W., Tian, J., Hu, J., \& Peng, G. et al. (2013). Development and systematic oxidative stress of a rat model of chronic bronchitis and emphysema induced by biomass smoke. Experimental Lung Research, 39(6), 229-240. doi: 10.3109/01902148.2013.797521

20. Janssen, N. A., Hoek, G., Simic-Lawson, M., Fischer, P., van Bree, L., ten Brink, H., Keuken, M., Atkinson, R. W., Anderson, H. R., Brunekreef, B., \& Cassee, F. R. (2011). Black carbon as an additional indicator of the adverse health effects of airborne particles compared with PM10 and PM2.5. Environmental health perspectives, 119(12), 1691-1699. https://doi.org/10.1289/ehp.1003369

21. Kar, A., Rehman, I. H., Burney, J., Puppala, S. P., Suresh, R., Singh, L., ... Ramanathan, V. (2012). Real-time assessment of black carbon pollution in Indian households due to traditional and improved biomass cookstoves. Environmental Science and Technology, 46(5), 2993-3000. https://doi.org/10.1021/es203388g

22. Kurmi, O., Semple, S., Simkhada, P., Smith, W., \& Ayres, J. (Mar de 2010). COPD and chronic bronchitis risk of indoor air pollution from solid fuel: a systematic review and meta-analysis. Thorax, 65(3), 221-8. 
23. Li, S., Xu, J., Jiang, Z., Luo, Y., Yang, Y., \& Yu, J. (2019). Correlation between indoor air pollution and adult respiratory health in Zunyi City in Southwest China: situation in two different seasons. BMC Public Health, 19(1). doi: 10.1186/s12889-019-7063-Z

24. Li, Z., Commodore, A., Hartinger, S., Lewin, M., Sjödin, A., \& Pittman, E., Naeher,L. (2016). Biomonitoring Human Exposure to Household Air Pollution and Association with Self-reported Health Symptoms - A Stove Intervention Study in Peru. Environment International, 97, 195-203. doi: 10.1016/j.envint.2016.09.011

25. Li, Z., Che, W., Lau, A. K. H., Fung, J. C. H., Lin, C., \& Lu, X. (2019). A feasible experimental framework for field calibration of portable light-scattering aerosol monitors: Case of TSI DustTrak. Environmental Pollution, 255, 113136. https://doi.org/10.1016/j.envpol.2019.113136

26. Lilliefors, H. W. (1967). On the Kolmogorov-Smirnov Test for Normality with Mean and Variance Unknown. Journal of the American Statistical Association, 62(318), 399-402. https://doi.org/10.1080/01621459.1967.10482916

27. Lim, S., Vos, T., Flaxman, A., Danaei, G., Shibuya, K., Adair-Rohani, H., . . Blore, J. (2012). A comparative risk assessment of burden of disease and injury attributable to 67 risk factors and risk factor clusters in 21 regions, 1990-2010: a systematic analysis for the Global Burden of Disease Study 2010. Lancet, 15(380), 2224-60doi: doi:10.1016/S0140-6736(12)61766-8.

28. Liñán Cortés, S., Cobos Barroso, N., \& Reverté Bover, C. (2008). Exploración funcional respiratoria (pp. 41-70). España: Asociación Española de Pediatría. Recuperado de https://www.aeped.es/protocolos/

29. MacCarty, N., Still, D., \& Ogle, D. (2010). Fuel use and emissions performance of fifty cooking stoves in the laboratory and related benchmarks of performance. Energy for Sustainable Development, 14(3), 161-171. https://doi.org/10.1016/j.esd.2010.06.002

30. McNamara, M. L., Thornburg, J., Semmens, E. O., Ward, T. J., \& Noonan, C. W. (2017). Reducing indoor air pollutants with air filtration units in wood stove homes. Science of the Total Environment, 592, 488-494. https://doi.org/10.1016/j.scitotenv.2017.03.111

31. Miller, M. R., Hankinson, J., Brusasco, V., Burgos, F., \& Casaburi, R. (2005). Standardisation of spirometry. Series ATS/ERS Task Force: Standardisation of Lung Function Testing. European Respiratory Journal, 26, 319-338.

32. Naeher, L., Brauer, M., Lipsett, M., Zelikoff, J., Simpson, C., Koenig, J., \& Smith, K. (Jan de 2007). Woodsmoke health effects: a review. Inhal Toxicol, 19(1), 67-106.

33. Pandey, M. R., Regmi, H. N., Neupane, R. P., Gautam, A., \& Bhandari, D. P. (1985). Domestic smoke pollution and respiratory function in rural Nepal. The Tokai journal of experimental and clinical medicine, 10(4), 471-481.

34. Pratiti, R., Vadala, D., Kalynych, Z., \& Sud, P. (2020). Health effects of household air pollution related to biomass cook stoves in resource limited countries and its mitigation by improved cookstoves. Environmental Research, 186(March), 109574. https://doi.org/10.1016/j.envres.2020.109574

35. Pellegrino, R., Viegi, G., Brusasco, V., Crapo, R., Burgos, F., Casaburi, R., . . Jensen, R. J. (2005). Interpretative strategies for lung function tests. Eur Respir J, 26(5), 948-68.

36. Perera, I. E., \& Litton, C. D. (2015). Quantification of Optical and Physical Properties of Combustion-Generated Carbonaceous Aerosols (2.5) Using Analytical and Microscopic Techniques. Fire technology, 51(2), 247-269. https://doi.org/10.1007/s10694-013-0376-z

37. Price-Allison, A., Lea-Langton, A. R., Mitchell, E. J. S., Gudka, B., Jones, J. M., Mason, P. E., \& Williams, A. (2019). Emissions performance of high moisture wood fuels burned in a residential stove. Fuel, 239(August 2018), 1038-1045. https://doi.org/10.1016/j.fuel.2018.11.090

38. Pope, D., Diaz, E., Smith-Sivertsen, T., Lie, R., Bakke, P., \& Balmes, J. et al. (2015). Exposure to Household Air Pollution from Wood Combustion and Association with Respiratory Symptoms and Lung Function in Nonsmoking Women: Results from the RESPIRE Trial, Guatemala. Environmental Health Perspectives, 123(4), 285-292. doi: 10.1289/ehp.1408200

39. Rivas, I., Mazaheri, M., Viana, M., Moreno, T., Clifford, S., He, C., ... Querol, X. (2017). Identification of technical problems affecting performance of DustTrak DRX aerosol monitors. Science of the Total Environment, 584-585, 849-855. https://doi.org/10.1016/j.scitotenv.2017.01.129

40. Romero de Ávila Cabezón, G., Gonzálvez Rey, J., Rodríguez Estévez, C., Timiraos Carrasco, R., Molina Blanco, M., Galego Riádigos, M., .. . Pérez Amor, R. (2013). Las 4 reglas de la espirometría. Cad Aten Primaria, $20,7$.

41. Rumchev, K., Zhao, Y., \& Spickett, J. (2017). Health Risk Assessment of Indoor Air Quality, Socioeconomic and House Characteristics on Respiratory Health among Women and Children of Tirupur, South India. International journal of environmental research and public health, $14(4), 429$. https://doi.org/10.3390/ijerph14040429

42. Secretaría Distrital de Ambiente de Bogotá. (2019). Informe mensual de calidad del aire de Bogotá (February). Recuperado de: http://rmcab.ambientebogota.gov.co/Pagesfiles/IM1902\%20INFORME\%20MENSUAL\%20DE\%20CALIDAD\%20DEL\%20AIRE\%20Febrero\%202019.pdf

43. Soto-Moreno, J., \& Ballester-Díez, F. (2013). Contaminación del aire de interiores en hogares en situación de pobreza extrema en Colombia. Rev. salud pública, 15(1), 80-89. Obtenido de https://www.scielosp.org/article/ssm/content/raw/? resource_ssm_path=/media/assets/rsap/v15n1/v15n1a08.pdf

44. Steinvil, A., Kordova-Biezuner, L., Shapira, I., Berliner, S., \& Rogowski, O. (2008). Short-term exposure to air pollution and inflammation-sensitive biomarkers. Environmental Research, 106(1), 51-61.

45. Steinvil, A., Cohen, M., Shapira, I., Berliner, S., Rogowski, O., Fireman, E., \& Kordova-Biezuner, L. (2009). Environmental Air Pollution Has Decremental Effects on Pulmonary Function Test Parameters Up to One Week After Exposure. The American Journal Of The Medical Sciences, 338(4), $273-279$. doi: 10.1097/maj.0b013e3181adb3ed

46. Swiston, J.R., Davidson, W., Attridge, S., Li, G.T., Brauer, M., van Eeden, S.F., 2008. Wood smoke exposure induces a pulmonary and systemic inflammatory response in firefighters. The European Respiratory Journal 32, 129-138. 
47. TSI. (2018). Operation and Service Manual, Indoor Air Quality Monitor, Model 7575. Recuperado de: https://www.tsi.com/getmedia/a9ce2668-b27b41d1-961b-a01fc8e7933d/7575-Q-Trak-Op_Svc_Mnl_6004850?ext=.pdf

48. Van Vliet, E., Kinney, P., Owusu-Agyei, S., Schluger, N., Ae-Ngibise, K., \& Whyatt, R., . . Asante,K. (2019). Current respiratory symptoms and risk factors in pregnant women cooking with biomass fuels in rural Ghana. Environment International, 124, 533-540. doi: 10.1016/j.envint.2019.01.046

49. Wang, F., Meng, D., Li, X., \& Tan, J. (2016). Indoor-outdoor relationships of PM2.5in four residential dwellings in winter in the Yangtze River Delta, China. Environmental Pollution, 215, 280-289. https://doi.org/10.1016/j.envpol.2016.05.023

50. Wang, M., Aaron, C., Madrigano, J., Hoffman, E., Angelini, E., Yang, J., Kinney, P. (2019). Association Between Long-term Exposure to Ambient Air Pollution and Change in Quantitatively Assessed Emphysema and Lung Function. JAMA, 322(6), 546-556. doi:10.1001/jama.2019.10255

51. Wierzbicka A., Licina H., Omelekhina Y., Nilsson P.T., Gudmundsson A. (2019) Black Carbon Concentrations Inside and Outside Occupied Residences. In: Johansson D., Bagge H., Wahlström Å. (eds) Cold Climate HVAC 2018. CCC 2018. Springer Proceedings in Energy. Springer, Cham. https://doi org.ezproxy.unal.edu.co/10.1007/978-3-030-00662-4_72

\section{Tables}

Table 1. Criteria for monitoring air pollutants

\begin{tabular}{|c|c|c|}
\hline Criterion & & Description \\
\hline Sample size & & homes -68 people \\
\hline Type of environment & & homes in Usme, Bogotá \\
\hline Measurement site & & Room \\
\hline Particle size & & $2.5 \mu \mathrm{m}$ \\
\hline \multirow{3}{*}{ Types of monitoring } & PM & DustTrak II 8530 \\
\hline & $\mathrm{BC}$ & MicroAethalometer (AE51) \\
\hline & $\mathrm{CO}$ & 7575 model Q-trak \\
\hline Continuous monitoring time & \multicolumn{2}{|r|}{$48 \mathrm{~h}$} \\
\hline Equipment height from the ground & \multicolumn{2}{|r|}{$1.6 \mathrm{~m}$} \\
\hline \multirow[t]{2}{*}{ Correction factors } & PM & 1.65 \\
\hline & $\mathrm{BC}$ & $\begin{array}{c}\mathrm{BC}_{\mathrm{c}}=\frac{\mathrm{BC}_{\mathrm{m}}}{\mathrm{K}} \\
\mathrm{K}=0,88 * \exp \exp \left(-\frac{\mathrm{ATN}}{100}\right) \\
+0,13\end{array}$ \\
\hline
\end{tabular}

Table 2. Characteristics of the study population 


\begin{tabular}{|c|c|c|c|c|}
\hline Variables & Recount & $\mathrm{N}$ column percentage & Media & Standard deviation \\
\hline \multirow[t]{2}{*}{ Sex } & Female & 46 & $67.6 \%$ & \\
\hline & Male & 22 & $32.4 \%$ & \\
\hline \multirow[t]{2}{*}{ History of smoking } & No & 61 & $89.7 \%$ & \\
\hline & Yes & 7 & $10.3 \%$ & \\
\hline \multirow[t]{2}{*}{ Type of participant } & Caretaker/Relative & 47 & $69.1 \%$ & \\
\hline & Disabled person & 21 & $30.9 \%$ & \\
\hline \multirow[t]{2}{*}{ Diagnosis of spirometry alteration } & No & 61 & $89.7 \%$ & \\
\hline & Yes & 7 & $10.3 \%$ & \\
\hline \multirow[t]{2}{*}{ Restriction pattem } & No & 63 & $92.6 \%$ & \\
\hline & Yes & 5 & $7.4 \%$ & \\
\hline \multirow[t]{2}{*}{ Obstruction pattern } & No & 67 & $98.5 \%$ & \\
\hline & Yes & 1 & $1.5 \%$ & \\
\hline \multirow[t]{2}{*}{ Use of biomass for cooking food } & No & 10 & 14.7 & \\
\hline & Yes & 58 & 85.3 & \\
\hline Age & & & 42.0 años & 20.3 \\
\hline Height & & & $154.0 \mathrm{~cm}$ & 10.5 \\
\hline Weight & & & $62.4 \mathrm{~kg}$ & 17.8 \\
\hline BMI & & & $25.9 \mathrm{~kg} / \mathrm{m}$ & 5.8 \\
\hline TEORICO_FVC & & & $97.2605 \%$ & 13.3279 \\
\hline TEORICO_FEV1 & & & $93.5097 \%$ & 15.1734 \\
\hline TEORICO_PEF & & & $77.3084 \%$ & 23.4125 \\
\hline TEORICO_FEF75 & & & $86.3016 \%$ & 31.4392 \\
\hline TEORICO_FEF2575 & & & $89.4356 \%$ & 29.2440 \\
\hline TEORICO_FET & & & $76.3603 \%$ & 25.3415 \\
\hline TEORICO_FEV1/FVC & & & $96.9474 \%$ & 10.4586 \\
\hline
\end{tabular}

Table 3. Interaction between indoor air quality pollutants and respiratory variables 


\begin{tabular}{|c|c|c|c|c|c|c|c|c|}
\hline Variable & Index & $\mathrm{PM}_{2.5}$ & $\mathrm{BC}$ & $\mathrm{CO}$ & FVC & FEV1 & PEF & FEV1/FVC \\
\hline \multirow[t]{3}{*}{$\mathrm{PM}_{2.5}$} & Correlation coefficient & 1.0 & $.702^{\star \star}$ & .255 & -.109 & -.090 & -.097 & .015 \\
\hline & Sig. (bilateral) & & .000 & .078 & .375 & .467 & .434 & .903 \\
\hline & $\mathrm{N}$ & 68 & 52 & 49 & 68 & 68 & 68 & 68 \\
\hline \multirow[t]{3}{*}{$B C$} & Correlation coefficient & $.702^{\star \star}$ & 1.000 & .297 & -.061 & -.088 & -.098 & -.141 \\
\hline & Sig. (bilateral) & .000 & & .074 & .666 & .537 & .488 & .318 \\
\hline & $N$ & 52 & 52 & 37 & 52 & 52 & 52 & 52 \\
\hline \multirow[t]{3}{*}{ CO } & Correlation coefficient & .255 & .297 & 1.000 & -.230 & $-.297^{\star}$ & $-.421^{\star *}$ & $-.390^{\star \star}$ \\
\hline & Sig. (bilateral) & .078 & .074 & & .112 & .038 & .003 & .006 \\
\hline & $\mathrm{N}$ & 49 & 37 & 49 & 49 & 49 & 49 & 49 \\
\hline \multirow[t]{3}{*}{ FVC } & Correlation coefficient & -.109 & -.061 & -.230 & 1.000 & $.950^{\star \star}$ & $.756^{\star \star}$ & .039 \\
\hline & Sig. (bilateral) & .375 & .666 & .112 & & .000 & .000 & .753 \\
\hline & $\mathrm{N}$ & 68 & 52 & 49 & 68 & 68 & 68 & 68 \\
\hline \multirow[t]{3}{*}{ FEV1 } & Correlation coefficient & -.090 & -.088 & $-.297^{\star}$ & $.950^{\star *}$ & 1.000 & $.770^{\star \star}$ & $.277^{\star}$ \\
\hline & Sig. (bilateral) & .467 & .537 & .038 & .000 & & .000 & .022 \\
\hline & $\mathrm{N}$ & 68 & 52 & 49 & 68 & 68 & 68 & 68 \\
\hline \multirow[t]{3}{*}{ PEF } & Correlation coefficient & -.097 & -.098 & $-.421^{\star \star}$ & $.756^{* *}$ & $.770^{\star \star}$ & 1.000 & $.336^{\star *}$ \\
\hline & Sig. (bilateral) & .434 & .488 & .003 & .000 & .000 & & .005 \\
\hline & $\mathrm{N}$ & 68 & 52 & 49 & 68 & 68 & 68 & 68 \\
\hline \multirow[t]{3}{*}{ FEV1/FVC } & Correlation coefficient & .015 & -.141 & $-.390^{* *}$ & .039 & $.277^{\star}$ & $.336^{* *}$ & 1.000 \\
\hline & Sig. (bilateral) & .903 & .318 & .006 & .753 & .022 & .005 & \\
\hline & $\mathrm{N}$ & 68 & 52 & 49 & 68 & 68 & 68 & 68 \\
\hline
\end{tabular}

${ }^{*} \mathrm{p}-\mathrm{val}<0,05$

${ }^{* *} \mathrm{p}-\mathrm{val}<0,01$

Table 4. Negative correlations between spirometry parameters and indoor air carbon monoxide concentration 


\begin{tabular}{|c|c|c|c|c|c|c|c|}
\hline \multirow[t]{2}{*}{ Pulmonary function measure } & \multirow[t]{2}{*}{ Model } & \multirow[t]{2}{*}{ B } & \multirow[t]{2}{*}{ Standard error } & \multirow[t]{2}{*}{$\mathrm{t}$} & \multirow[t]{2}{*}{ Sig. } & \multicolumn{2}{|c|}{$95 \%$ confidence interval for } \\
\hline & & & & & & Lower limit & Upper limit \\
\hline \multirow[t]{2}{*}{ Non adjusted FEV1/FVC } & Constant & 97.808 & 1.633 & 59.889 & 0.000 & 94.524 & 101.091 \\
\hline & $\mathrm{co}$ & -17.057 & 6.422 & -2.656 & 0.011 & -29.970 & -4.145 \\
\hline \multirow[t]{2}{*}{ Adjusted FEV1/FVC } & Constant & 37.088 & 26.639 & 1.392 & 0.171 & -16.672 & 90.847 \\
\hline & $\mathrm{co}$ & -18.750 & 6.110 & -3.069 & 0.004 & -31.080 & -6.420 \\
\hline \multirow[t]{2}{*}{ Theoretical non adjusted FEV1 } & Constant & -6.889 & 1.328 & -5.187 & 0.000 & -9.591 & -4.187 \\
\hline & $\mathrm{co}$ & -24.171 & 8.008 & -3.018 & 0.004 & -40.282 & -8.06 \\
\hline \multirow[t]{2}{*}{ Adjusted FEV1 } & Constant & 95.126 & 33.920 & 2.804 & 0.008 & 26.673 & 163.580 \\
\hline & $\mathrm{co}$ & -23.969 & 7.780 & -3.081 & 0.004 & -39.669 & -8.269 \\
\hline \multirow[t]{2}{*}{ Theoretical non adjusted PEF } & Constant & 78.313 & 3.108 & 25.198 & 0.000 & 72.064 & 84.562 \\
\hline & $\mathrm{co}$ & -29.891 & 12.222 & -2.446 & 0.018 & -54.464 & -5.318 \\
\hline \multirow[t]{2}{*}{ Adjusted PEF } & Constant & -5.948 & 53.959 & -.110 & 0.913 & -114.843 & 102.946 \\
\hline & $\mathrm{CO}$ & -28.993 & 12.376 & -2.343 & 0.024 & -53.968 & -4.018 \\
\hline
\end{tabular}

Table 5. Comparison of $\mathrm{CO}$ concentrations in this study and the ambient concentrations of the city of Bogotá

\begin{tabular}{|lllll|}
\hline \multicolumn{2}{|l}{ Present study - Rural intramural monitoring } & \multicolumn{4}{l|}{ Urban monitoring stations - Bogotá** } \\
\hline Fuel: Gas & Fuel: Woodfire & Tunal & Puente Aranda & Fontibon \\
\hline $0 \mathrm{ppm}$ & $1.4 \mathrm{ppm}^{\star}$ & $0.84 \mathrm{ppm}$ & $1.12 \mathrm{ppm}$ & $0.29 \mathrm{ppm}$ \\
\hline
\end{tabular}

* 8h highest average recorded in this study. ${ }^{* \star}$ Average 8h for the month of February 2019.

\section{Figures}

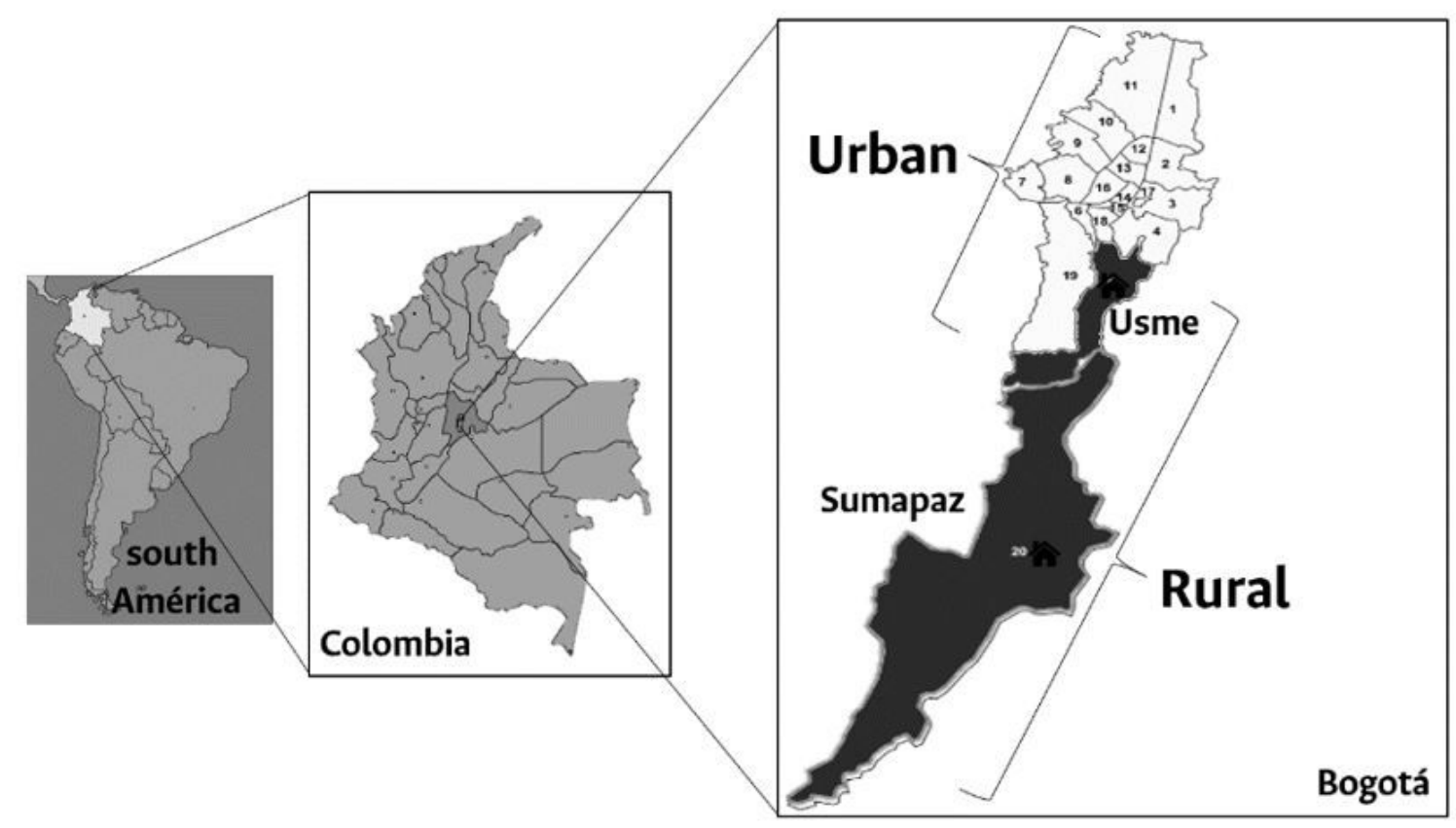


Figure 1

Usme district in Bogota
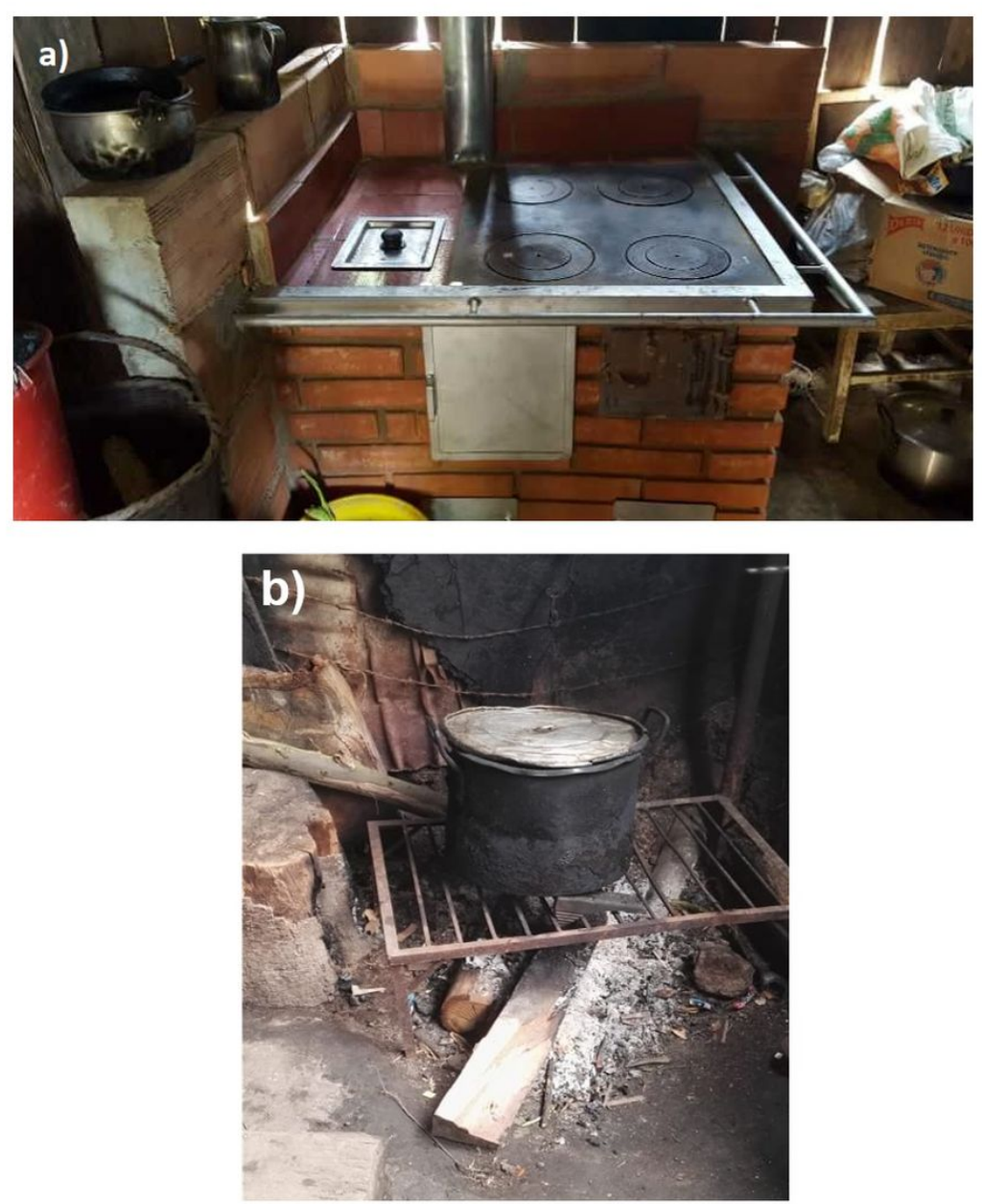

Figure 2

Stove types, a) Modified stove, b) Traditional type of stove 

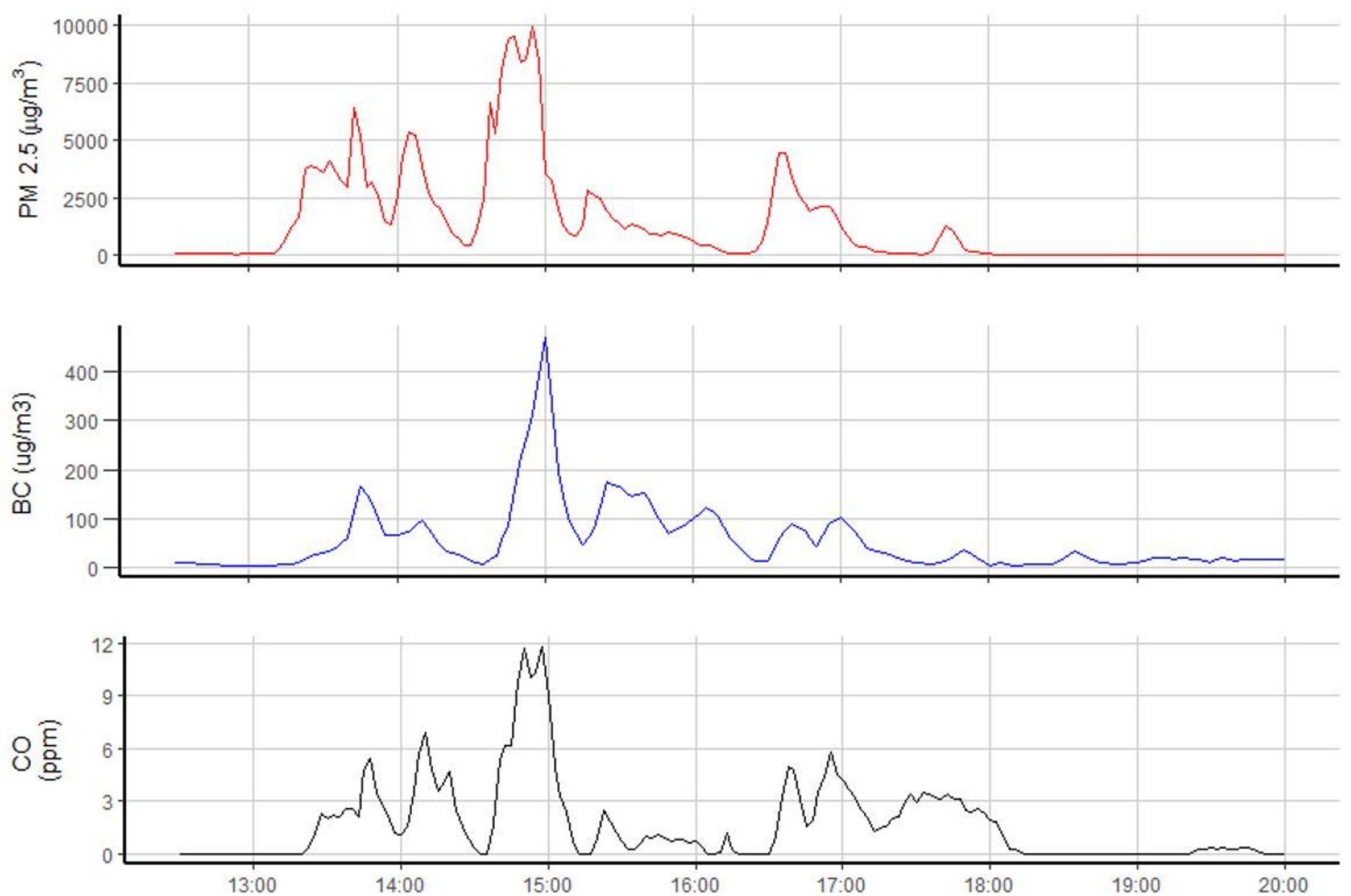

Figure 3

Daytime concentrations of PM2.5, BC and CO in homes that use firewood. 

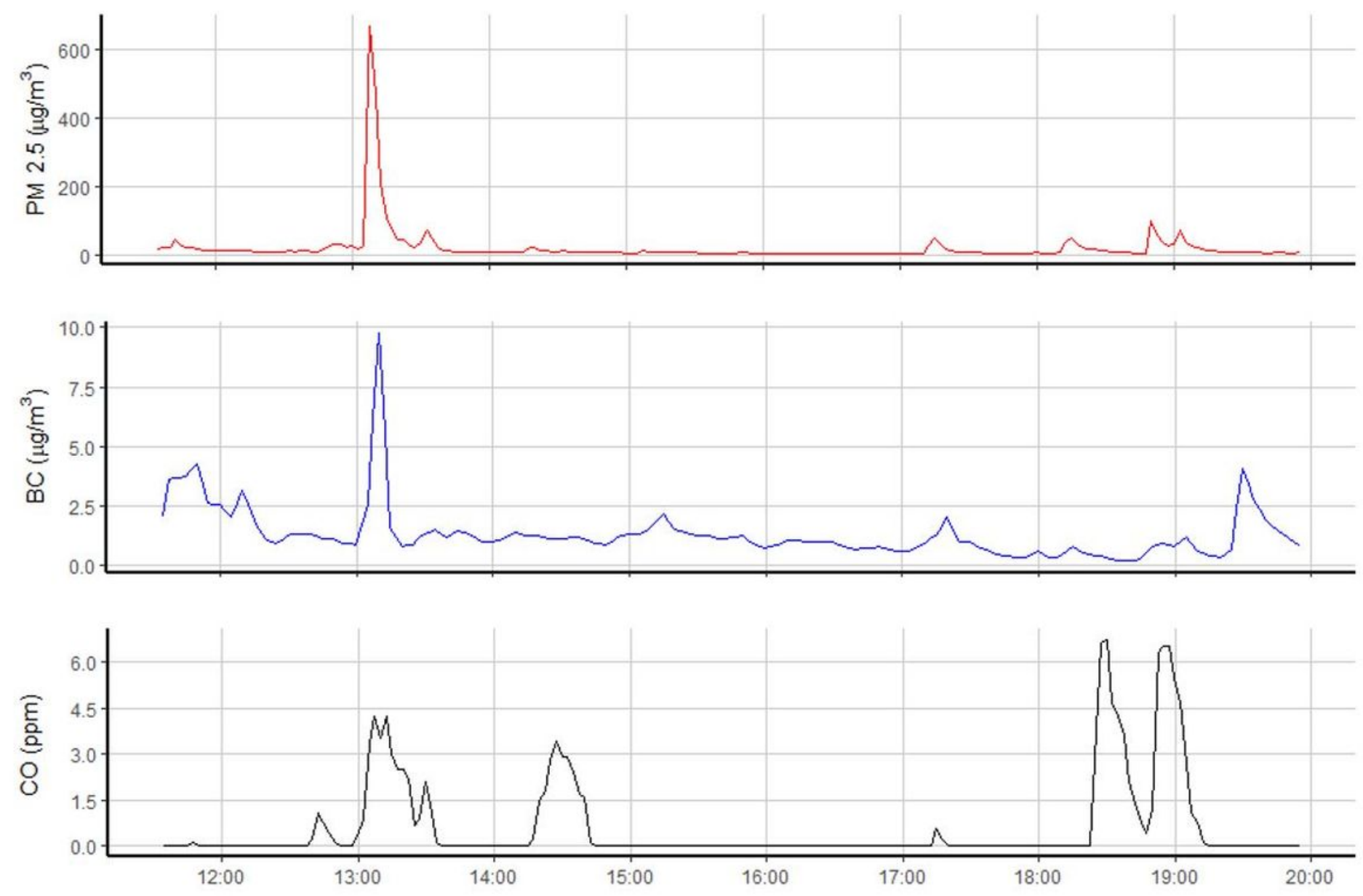

Figure 4

Daytime concentrations of PM2.5, black carbon and $\mathrm{CO}$ in homes that use gas. 